\title{
Increasing Students' Ability In Writing Procedure Text Through Learning Model Pictures And Pictures
}

\author{
Dina Syarifah Nasution ${ }^{1}$, Muhammad Hasyimsyah Batubara ${ }^{2}$, Rahmayana ${ }^{3}$ \\ ${ }^{1}$ STAIN Mandailing Natal Sumut, ${ }^{2,3}$ IAIN Takengon, Aceh Tengah, Aceh, Indonesia \\ 1dinasyarifahnasution1982@gmail.com, muhammad.hasyimsyahbatubara@gmail.com*2,3 \\ * corresponding author
}

\section{ARTICLE INFO}

Article history

Received 15 July 2021

Revised 20 September 2021

Accepted 10 November 2021

Keywords

Keyword_1 Writing

Keyword_2 Procedure Text

Keyword_3 Picture

\begin{abstract}
This study investigated increasing students' ability to write procedure text through learning model pictures and pictures in ninth grade at SMPN 4 Takengon. The study used the quantitative method with experimental design. To collect the data, the writer uses the test (pre-test and post-test). The population in this research is all students of the ninth grade in SMPN 4 Takengon, which consists of 196 students. The writer uses purposive sampling to take the sample in this research. A first group is an experimental group, which amounts to 37 students, and the second group is the control group which amounts to 37 students. The writer uses the t-test formula to analyze data in this research. The result of $t_{\text {score }}$ is 5,71. Compared with the $t_{\text {table }}$, the $t_{\text {score }}$ is higher, i.e., 5,71, than $t_{\text {table }}$ is 1,99 . It can be concluded that learning model pictures and pictures can increase students' ability in writing procedure text. The writer suggests that students try to write in English as habitual because it can help add more vocabulary and make the students have good writing.
\end{abstract}

This is an open access article under the CC-BY-SA license.

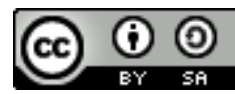

\section{INTRODUCTION}

Writing is one of the instrumental aspects of the language that should be mastered. By writing, someone means can apply memory, mind, ideas, and creativity. Writing is also one of the language skills used to communicate, not face to face with other people indirectly. More comprehensive writing is an act of creating ideas that are poured into an article. Usually, someone makes it into the media. Writing skills are considered the most challenging language skills because they involve the ability or mastery of grammar, vocabulary, and spelling. Additionally, necessary or logical thinking skills mix words into meaningful sentences (Suyanto, 2008).

If we are students, writing skills need to be learned because these skills are an essential part of language learning and will be helpful for us. Meanwhile, English teachers in teaching are most likely to have students who have difficulties in writing lessons. Based on the writer's experience, when the writer was done teaching practice in SMPN 4 Takengon, the writer was found that one of the student's difficulties in learning English was to write the procedure text. In comparison, the procedure text is elementary. In their opinion, the procedure text is a complex text to write, and they lack understanding of how to begin writing a procedure text. Student's difficulties in writing the procedure text, probably due to the lack of media and the methods can not make them excited and interested in writing a text, especially procedure text. Thus, in the learning process procedure text, they stare at it and do not use media such as pictures or videos. 
Vol. 1, No. 1, July - December 2021, pp. 8-19

According to Setiawan (2008), a procedure text is a text form that describes how to do or produce something through a series of actions or steps. Its means, It is a kind of text to illustrate and instructions for operating or creating something. Supposedly the students in junior high school have been able to create and develop the text as procedure text. Because the procedure text is elementary to understand, this text is also easy to find, and they often do the things that have sequence or steps, even though they do not realize it, such as serving instant noodles, turning on the computer, making a cup of coffee, etcetera.

However, researchers face current students who face difficulties in making procedure texts, even considering English lessons to be their enemy. So the method and presentation of learning must be made in such a way by involving them in cooperative, active, creative, and fun learning to better remember the lesson, especially in writing procedural texts. Teachers have started to use various learning models to improve students' ability to speak English, be it in writing, reading, speaking, and listening. The learning model is the method used and designed by the teacher in the learning process from the beginning to the end of the lesson. There are many types of learning models as mentioned by Istarani in his book "58 Innovative Learning Models," including picture and picture, non-example, number heads together, cooperative script, student team-achievement divisions, jigsaw, problem-based instructions, problem-centered learning, mind mapping, think pair and share, role-playing, debate, group investigation, talking stick, and others (Istarani, 2011).

Among the number of learning models, the writer chose the picture and picture learning model because it is considered more effective for students in ninth-grade junior high school. After all, this learning model can make the students enjoy it, and it uses pictures as a medium. Thus, the students are more interested, plus they have to arrange pictures into logical sequence first, then they start writing. Students will feel that they are playing while learning. Picture and picture are very suitable with the procedure text because this text has stepped in its generic structure, and picture and picture also have stepped in applying it (giving the media as the picture that has a logical sequence). The students have to arrange the pictures, and then they write some explanations about the pictures. For example, how to make a cup of coffee, how to make instant noodles, etcetera.

If this learning model is not implemented in ninth grade at SMPN 4 Takengon, the writer worries they will not make procedure text. The writer considers learning models picture and picture able to increase students' ability in writing procedure text, as it uses the picture media comes with a caption, of course, it can help students remember the lesson. The increasing English result needs the teacher's effort to take the initiative to motivate them to learn English. Because of the case above, the writer is interested in studying and exploring. The writer will conduct the in-depth study, and the title is increasing students' ability in writing procedure text through learning model picture and picture in ninth grade at SMPN 4 Takengon.

\section{LITERATURE REVIEW}

\subsection{Writing}

Writing is an activity of conveying ideas, intentions, emotions, messages, and ideas to the reader by using letters, words, phrases, sentences, paragraphs, text, and punctuation (Brown, 2001; Boardman, 2002; Nunan, 2003: 88; Harmer, 2004). Even the writing can share information or science with the reader. It is lowered or describe graphical symbols that describe a language that a person understands to the graphical symbols (Sampson, 1985: 27; Nöth, 1995: 259 in Batubara, 2021; Bukhari, 2010). Like speaking, writing is rooted in ideas and words. Children's experiences, firsthand and/or those lived through language, are the content of their writing. Written words, like spoken words, convey the emotions, knowledge, and perception of the writer (Ellis, 1989). 
Writing is a powerful way to think problems through because it helps you describe and name the conflicting parts of your thinking (Flower, 1989). It means that we have to pay attention to some things that support the result of our writing. In order for the quality of writing to be good, it must be supported with some good composition, such as good grammar and using punctuation correctly. In comparison, stages of writing are prewriting, writing, and rewriting (Hayes and Flower, 1980; Flower and Hayes, 1981; Richard, 2002; Oshima and Hogue, 2007; Johnson, 2008; Mitchell et al.,2017; Mitchell et al., 2017 in Batubara, 2021). However, Neman said that writing is a single process. It can, nevertheless, be analyzed in three stages prewriting, writing, and rewriting, experienced writers tend to combine these stages as they compose, but almost everyone who writes well follows them (Neman, 1989).

\subsection{Procedure Text}

According to Oxford Advanced Learner Dictionary, the procedure is a formal or official order or way of doing things (Hornby, \& Ashby, 2003). It is a type of text that tells us how something is done through a series of actions or steps (Departemen Pendidikan Nasional, 2004). In other words, it is a text that explains how to operate or make something, for example, how to make a cup of coffee, how to make the instant noodle, how to operate a computer, etcetera.

\subsection{Picture and Picture}

Picture and picture is a learning method that uses a picture that is paired or sorted into a logical sequence (Hamdani, 2011). The picture means "a painting or drawing" (Hornby, \& Ashby, 2003). The purpose of picture and picture here is for the teacher to use images to convey the material so that the students find their material concept in learning. It means that the teacher brought media such as a picture. But in contrast to the existing picture media. These images are interconnected and have a logical sequence. For example, how to make a cup of coffee or tea, there are images that are sorted according to the steps of making a cup of coffee or tea. It is a series of delivery of teaching materials by displaying real and direct pictures to the student so that the student can clearly grasp the true meaning of the teaching materials delivered to them.

\section{RESEARCH METHODOLOGY}

\subsection{Research Design}

The research design of this subject was conducted by using a quantitative approach based on experimental research. A quantitative approach is collecting data by using the statistic. Quantitative is the research demanded using the number, from collecting data, interpretation to the data, and appearance of the result (Suharsimi, 2006). The writer chooses the experimental research to know the students' ability after they have been taught procedure text through the picture and picture learning model. The experimental class is the class that receives the new treatment, and the control class is the class that receives the different treatment or is treated as usual. In comparison, the test was given in one class divided into two classes, in first as experimental class and second class as control class, and to give of the test that is pre-test and post-test.

\subsection{Source of the Data}

In the research, the persons that will be researched in SMPN 4 Takengon. The population is all of the research subjects, and it was taken from ninth grade (IX) at SMPN 4 Takengon, where the total member 196 students. The sample is part of the population. The writer used purposive sampling in this research because the sample was taken from ninth grade only (Suharsimi, 2006). The writer divided students into two groups, the first 
group (IX3) as the experimental group, which consists of 37 students, and the second group (IX5) as the control group consisting of 37 students. In the experimental group, the students will give a test by the writer, and the writer will answer only then the writer as the assessment only. In the control group, the writer is the motivator and explains before the students answer the question.

\subsection{The technique of Data Collection}

The technique of data collection played an essential role in conducting any research. So that the result of the study would be valid, in this research, the writer used a questionnaire and test.

\subsection{Data Analysis}

After conducting the test, the writer gives a score for the writing ability of the students. The following are the steps that the writer use for calculating the student's increase in writing. To know the student's score, the researcher used the analysis method with the formulation of a t-test.

$$
t=\frac{M_{x}-M y}{\sqrt{\left(\frac{x^{2}+y^{2}}{n_{x}+n_{y}-2}\right)\left(\frac{1}{n_{x}}+\frac{1}{n_{y}}\right)}}
$$

Where:

$t \quad=$ the score

$M_{x} \quad=$ mean of experimental class

$M_{y} \quad=$ mean of control class

$x^{2} \quad=$ deviation score of experimental class

$y^{2} \quad=$ deviation score of control class

$n_{x} \quad=$ the sample of experimental class

$n_{y} \quad=$ the sample of control class (Suharsimi, 2006).

\section{FINDINGS}

\subsection{The Result of Pre-Test and Post-Test Experiment Group and Control Group}

The writer put the data in the table to calculate the data, and the following table is the pre-test and post-test of the experimental and control groups.

Table 1. The score of pre-test and post-test at $\mathrm{IX}^{3}$ class as experimental group

\begin{tabular}{llcc}
\hline No & Name & Pre-Test & Post-Test \\
\hline 1 & Afrizal Syahputra & 30 & 60 \\
2 & Aginda Putri Fahira & 40 & 70 \\
3 & Aini Serungke & 40 & 80 \\
4 & Akbar & 30 & 70 \\
5 & Alfi Muklis & 30 & 70 \\
6 & Amin Rais & 30 & 60 \\
7 & Ays Sarech Salenko & 60 & 80 \\
8 & Dara Naimatul Jannah & 40 & 80 \\
9 & Dewi Liana & 50 & 70 \\
10 & Edowin Ramayadi & 30 & 80 \\
11 & Fahrur Rozi & 30 & 80 \\
12 & Fira Fadilah & 40 & 80 \\
13 & Fitrahul Ramadhan & 30 & 70 \\
14 & Fitriyani Simehate & 40 & 70 \\
15 & Harisin Fatwa & 30 & 80
\end{tabular}




\begin{tabular}{llcc}
16 & Hildayatunnisa & 40 & 80 \\
17 & Ivan Ridho Juanda Pane & 30 & 70 \\
18 & Kemal Pasha Al-Kindi & 50 & 80 \\
19 & Kenko Rizqullah & 30 & 70 \\
20 & Khairunnisa Hasimi & 40 & 80 \\
21 & M. Al Kindi & 50 & 80 \\
22 & M. Iqbal & 40 & 70 \\
23 & Mawaddah Ayunisa & 30 & 60 \\
24 & May Deni Syahputra & 30 & 60 \\
25 & Mazdan Al Qaedi & 40 & 80 \\
26 & Nadira Ataya & 50 & 80 \\
27 & Pita Mandalia & 20 & 80 \\
28 & Rizki Wiranata & 30 & 80 \\
29 & Sari Wahdini & 40 & 80 \\
30 & Shinta Nuria M. B. & 40 & 80 \\
31 & Suhaini & 40 & 70 \\
32 & Sulfiandi & 60 & 80 \\
33 & Teguh Sala Mukti & 30 & 70 \\
34 & Tria Anastasya & 40 & 70 \\
35 & Tuti Alawiya & 30 & 80 \\
36 & Wahyunisa & 50 & 80 \\
37 & Wirna Silva Putri & 30 & 80 \\
\hline & Total & 1390 & 2760 \\
& Average & 37,57 & 74,59 \\
& Maximum & 60 & 60 \\
& Minimum & 20 & \\
\hline
\end{tabular}

The table above shows that the pre-test score from 37 students is 1390, and the posttest score is 2760 . The average score is 37,57 in the pre-test, and in the post-test get 74,59. The maximum score in the pre-test is 60 , and in the post-test is 80 . Then the minimum score in pre-test is 20, and in post-test is 60 . follows:

The score of pre-test and post-test of the students of $\mathrm{IX}^{5}$ in the control group as

Table 2. The score of the pre-test and post-test IX ${ }^{5}$ class as control group

\begin{tabular}{llcc}
\hline No & Name & Pre-Test & Post-Test \\
\hline 1 & Ajran Tuahmiko & 40 & 50 \\
2 & Andika Pratama & 30 & 70 \\
3 & Andrea & 40 & 60 \\
4 & Asnan Rikta & 30 & 60 \\
5 & Buge Aramiko & 30 & 70 \\
6 & Elda Safitri & 40 & 60 \\
7 & Ellyana & 40 & 70 \\
8 & Erliana Fitri & 40 & 70 \\
9 & Fahri Arico & 30 & 60 \\
10 & Fatlyza Rahayu & 40 & 60 \\
11 & Finta Ayu Lyna & 40 & 60 \\
12 & Fitri Ani & 40 & 60 \\
13 & Hardiansyah Putra & 40 & 50 \\
14 & Idham Khaliq & 30 & 50 \\
15 & Jufri Temas Miko & 30 & 50
\end{tabular}


Vol. 1, No. 1, July - December 2021, pp. 8-19

\begin{tabular}{llcc}
16 & Johandi Munara & 40 & 70 \\
17 & Kasnur Miswari & 30 & 70 \\
18 & Khairumi Asria Putri & 60 & 70 \\
19 & Khairunnisa & 50 & 70 \\
20 & M. Ali Agung & 40 & 70 \\
21 & M. Arfan & 40 & 50 \\
22 & M. Iqbal Arican & 40 & 50 \\
23 & M. Rifki & 30 & 40 \\
24 & Maharaini & 50 & 70 \\
25 & Masita Putri Sabila & 30 & 70 \\
26 & Nazahara Raihan & 30 & 60 \\
27 & Nike Arami & 50 & 70 \\
28 & Nurul Fathonah & 40 & 70 \\
29 & Rian Ari Wantona & 30 & 50 \\
30 & Rika Piana & 30 & 70 \\
31 & Risky Akbar & 20 & 60 \\
32 & Risky Mursada & 30 & 40 \\
33 & Sauma Destiyanni & 50 & 70 \\
34 & Siswy Bunga Pramiga & 60 & 70 \\
35 & Sri Wahyuni & 40 & 70 \\
36 & Tuah Tamara & 20 & 40 \\
37 & Win Syahara & 30 & 60 \\
\hline & Total & 1380 & 2260 \\
& Average & 37,30 & 61,08 \\
& Maximum & 60 & 70 \\
& Minimum & 20 & 40 \\
\hline
\end{tabular}

The table above shows the pre-test, and post-test scores in the control group, the pretest score from 37 students are 1380, and the score in post-test is 2260 . The average score is 37,30 in the pre-test, and in the post-test get 61,08 . The maximum score in the pre-test is 60 and in the post-test is 70 . Then the minimum score in the pre-test is 20 , and in the posttest is 40 .

\subsection{Data Analysis}

After the writer got the test result from the control and experimental groups, the writer would like to analyze the data using the t-test formula. To know the difference between the control and experimental groups, the writer uses a comparative analysis technique between the two classes as follows. The score analysis had to find out the deviation between pre-test and post-test in the experimental group as follows:

Table 3. The differences score of pre-test and post-test at $\mathrm{IX}^{3}$ as experimental group

\begin{tabular}{llcccc}
\hline No & Name & $\begin{array}{c}\text { Pre-Test } \\
\left(\mathrm{y}_{1}\right)\end{array}$ & $\begin{array}{c}\text { Post-Test } \\
\left(\mathrm{y}_{2}\right)\end{array}$ & $\begin{array}{c}\text { Deviation } \\
(\mathrm{d})\end{array}$ & $\begin{array}{c}\text { Squared } \\
\text { Deviation } \\
\left(\mathrm{d}^{2}\right)\end{array}$ \\
\hline 1 & Afrizal Syahputra & 30 & 60 & 30 & 900 \\
2 & Aginda Putri Fahira & 40 & 70 & 30 & 900 \\
3 & Aini Serungke & 40 & 80 & 40 & 1600 \\
4 & Akbar & 30 & 70 & 40 & 1600 \\
5 & Alfi Muklis & 30 & 70 & 40 & 1600 \\
6 & Amin Rais & 30 & 60 & 30 & 900 \\
7 & Ays Sarech Salenko & 60 & 80 & 20 & 400 \\
8 & Dara Naimatul Jannah & 40 & 80 & 40 & 1600
\end{tabular}


Vol. 1, No. 1, July - December 2021, pp. 8-19

\begin{tabular}{|c|c|c|c|c|c|}
\hline 9 & Dewi Liana & 50 & 70 & 20 & 400 \\
\hline 10 & Edowin Ramayadi & 30 & 80 & 50 & 2500 \\
\hline 11 & Fahrur Rozi & 30 & 80 & 50 & 2500 \\
\hline 12 & Fira Fadilah & 40 & 80 & 40 & 1600 \\
\hline 13 & Fitrahul Ramadhan & 30 & 70 & 40 & 1600 \\
\hline 14 & Fitriyani Simehate & 40 & 70 & 30 & 900 \\
\hline 15 & Harisin Fatwa & 30 & 80 & 50 & 2500 \\
\hline 16 & Hildayatunnisa & 40 & 80 & 40 & 1600 \\
\hline 17 & Ivan Ridho Juanda Pane & 30 & 70 & 40 & 1600 \\
\hline 18 & Kemal Pasha Al-Kindi & 50 & 80 & 30 & 900 \\
\hline 19 & Kenko Rizqullah & 30 & 70 & 40 & 1600 \\
\hline 20 & Khairunnisa Hasimi & 40 & 80 & 40 & 1600 \\
\hline 21 & M. Al Kindi & 50 & 80 & 30 & 900 \\
\hline 22 & M. Iqbal & 40 & 70 & 30 & 900 \\
\hline 23 & Mawaddah Ayunisa & 30 & 60 & 30 & 900 \\
\hline 24 & May Deni Syahputra & 30 & 60 & 30 & 900 \\
\hline 25 & Mazdan Al Qaedi & 40 & 80 & 40 & 1600 \\
\hline 26 & Nadira Ataya & 50 & 80 & 30 & 900 \\
\hline 27 & Pita Mandalia & 20 & 70 & 50 & 2500 \\
\hline 28 & Rizki Wiranata & 30 & 80 & 50 & 2500 \\
\hline 29 & Sari Wahdini & 40 & 80 & 40 & 1600 \\
\hline 30 & Shinta Nuria M. B. & 40 & 80 & 40 & 1600 \\
\hline 31 & Suhaini & 40 & 70 & 30 & 900 \\
\hline 32 & Sulfiandi & 60 & 80 & 20 & 400 \\
\hline 33 & Teguh Sala Mukti & 30 & 70 & 40 & 1600 \\
\hline 34 & Tria Anastasya & 40 & 70 & 30 & 900 \\
\hline 35 & Tuti Alawiya & 30 & 80 & 50 & 2500 \\
\hline 36 & Wahyunisa & 50 & 80 & 30 & 900 \\
\hline \multirow[t]{5}{*}{37} & Wirna Silva Putri & 30 & 80 & 50 & 2500 \\
\hline & Total & 1390 & 2750 & 1360 & 52800 \\
\hline & Average & 37,57 & 74,32 & 36.76 & 1427,03 \\
\hline & Maximum & 60 & 80 & 50 & 2500 \\
\hline & Minimum & 20 & 60 & 20 & 400 \\
\hline \multirow{5}{*}{$M x$} & $\sum d$ & & & & \\
\hline & $=\frac{}{n x}$ & & & & \\
\hline & 1360 & & & & \\
\hline & $=37$ & & & & \\
\hline & $=36,76$ & & & & \\
\hline \multirow{8}{*}{$x^{2}$} & $=\sum d^{2}-\underline{\sum d^{2}}$ & & & & \\
\hline & $=-2 a-n x$ & & & & \\
\hline & $(1360)^{2}$ & & & & \\
\hline & $=52000-37$ & & & & \\
\hline & $-52800-1849600$ & & & & \\
\hline & $=52000-37$ & & & & \\
\hline & $=52800-49989,19$ & & & & \\
\hline & $=2810,81$ & & & & \\
\hline
\end{tabular}


From the calculation of the data above, the writer can show that the mean of the experimental group $(M x)$ is 36,76 , and the deviation score of the experimental group $\left(x^{2}\right)$ is 2810,81

Table 4. The differences score of pre-test and post test at $\mathrm{IX}^{5}$ as control group

\begin{tabular}{|c|c|c|c|c|c|}
\hline No & Name & $\begin{array}{c}\text { Pre-Test } \\
\left(\mathrm{y}_{1}\right)\end{array}$ & $\begin{array}{c}\text { Post-Test } \\
\left(\mathrm{y}_{2}\right)\end{array}$ & $\begin{array}{l}\text { Deviation } \\
\text { (d) }\end{array}$ & $\begin{array}{c}\text { Squared } \\
\text { Deviation } \\
\left(\mathrm{d}^{2}\right)\end{array}$ \\
\hline 1 & Ajran Tuahmiko & 40 & 50 & 30 & 900 \\
\hline 2 & Andika Pratama & 30 & 70 & 40 & 1600 \\
\hline 3 & Andrea & 40 & 60 & 20 & 400 \\
\hline 4 & Asnan Rikta & 30 & 60 & 30 & 900 \\
\hline 5 & Buge Aramiko & 30 & 70 & 40 & 1600 \\
\hline 6 & Elda Safitri & 40 & 60 & 20 & 400 \\
\hline 7 & Ellyana & 40 & 70 & 30 & 900 \\
\hline 8 & Erliana Fitri & 40 & 70 & 30 & 900 \\
\hline 9 & Fahri Arico & 30 & 60 & 30 & 900 \\
\hline 10 & Fatlyza Rahayu & 40 & 60 & 20 & 400 \\
\hline 11 & Finta Ayu Lyna & 40 & 60 & 20 & 400 \\
\hline 12 & Fitri Ani & 40 & 60 & 20 & 400 \\
\hline 13 & Hardiansyah Putra & 40 & 50 & 10 & 100 \\
\hline 14 & Idham Khaliq & 30 & 50 & 20 & 400 \\
\hline 15 & Jufri Temas Miko & 30 & 50 & 20 & 400 \\
\hline 16 & Johandi Munara & 40 & 70 & 30 & 900 \\
\hline 17 & Kasnur Miswari & 30 & 70 & 40 & 1600 \\
\hline 18 & Khairumi Asria Putri & 60 & 70 & 10 & 100 \\
\hline 19 & Khairunnisa & 50 & 70 & 20 & 400 \\
\hline 20 & M. Ali Agung & 40 & 70 & 30 & 900 \\
\hline 21 & M. Arfan & 40 & 50 & 10 & 100 \\
\hline 22 & M. Iqbal Arican & 40 & 50 & 10 & 100 \\
\hline 23 & M. Rifki & 30 & 40 & 10 & 100 \\
\hline 24 & Maharaini & 50 & 70 & 20 & 400 \\
\hline 25 & Masita Putri Sabila & 30 & 70 & 40 & 1600 \\
\hline 26 & Nazahara Raihan & 30 & 60 & 30 & 900 \\
\hline 27 & Nike Arami & 50 & 70 & 20 & 400 \\
\hline 28 & Nurul Fathonah & 40 & 70 & 30 & 900 \\
\hline 29 & Rian Ari Wantona & 30 & 50 & 20 & 400 \\
\hline 30 & Rika Piana & 30 & 70 & 40 & 1600 \\
\hline 31 & Risky Akbar & 20 & 60 & 40 & 1600 \\
\hline 32 & Risky Mursada & 30 & 40 & 10 & 100 \\
\hline 33 & Sauma Destiyanni & 50 & 70 & 20 & 400 \\
\hline 34 & Siswy Bunga Pramiga & 60 & 70 & 10 & 100 \\
\hline 35 & Sri Wahyuni & 40 & 70 & 30 & 900 \\
\hline 36 & Tuah Tamara & 20 & 40 & 20 & 400 \\
\hline \multirow[t]{5}{*}{37} & Win Syahara & 30 & 60 & 30 & 900 \\
\hline & Total & 1380 & 2260 & 900 & 25400 \\
\hline & Average & 37,30 & 61,08 & 24,32 & 686,49 \\
\hline & Maximum & 60 & 70 & 40 & 1600 \\
\hline & Minimum & 20 & 40 & 10 & 100 \\
\hline
\end{tabular}




$$
\begin{aligned}
\text { My } & =\frac{\sum d}{n y} \\
& =\frac{900}{37} \\
& =24,32 \\
y^{2} & =\sum d^{2}-\frac{\left(\sum d\right)^{2}}{37} \\
& =25400-\frac{(900)^{2}}{37} \\
& =25400-\frac{810000}{37} \\
& =25400-21891,89 \\
& =3508,11
\end{aligned}
$$

From the data calculation above, the writer can show that the control group's mean $(M y)$ is 24,32 , and the deviation score of the control group $\left(y^{2}\right)$ is 3508,11 . From calculating the result of pre-test and post-test the experimental group and control group above, the writer can show as follow:

$$
\begin{aligned}
& M x=36,76 \\
& x^{2}=2810,81 \\
& N x=37 \\
& M y=24,32 \\
& y^{2}=3508,11 \\
& N y=37
\end{aligned}
$$

The formulated for computing the t-test was shown below:

$$
\begin{aligned}
\mathrm{t} & =\frac{M_{x}-M_{y}}{\sqrt{\left(\frac{\sum x^{2}+\sum y^{2}}{n_{x} n_{y}-2}\right)\left(\frac{1}{n_{x}}+\frac{1}{n_{y}}\right)}} \\
& =\frac{36,76-24,32}{\sqrt{\left(\frac{2810,81+3508,11}{37+37-2}\right)\left(\frac{1}{37}+\frac{1}{37}\right)}} \\
& =\frac{12,44}{\sqrt{\left(\frac{6318,92}{72}\right)\left(\frac{2}{37}\right)}} \\
& =\frac{12,44}{\sqrt{(87,7628)(0,054)}} \\
& =\frac{12,44}{\sqrt{4,74}} \\
& =\frac{12,44}{2,18} \\
& =5,71
\end{aligned}
$$

After the writer analyzes the data using the t-test formula, the result of the test shows that 5,71 the value $\mathrm{t}_{\text {score }}, 5,71$ is more than table 1,99 at the level significance 0,05 , it shows that the research hypothesis $\left(\mathrm{H}_{\mathrm{a}}\right)$ is accepted and the null hypothesis $\left(\mathrm{H}_{0}\right)$ is rejected. It means the learning model picture and picture increase students' ability in writing procedure text in English. 


\subsection{Testing Hypothesis}

The testing hypothesis should be made in other to know whether the hypothesis is accepted or rejected. In testing the hypothesis, the basic theory that the writer used was that the hypothesis is accepted if $t_{\text {score }}>t_{\text {table. }}$. The prove that hypothesis, it is important to find the degree of freedom $(\mathrm{df})$ by the following formula:

$$
\begin{aligned}
\mathrm{df} & =\mathrm{n}_{1}+\mathrm{n}_{2}-2 \\
& =37+37-2 \\
& =72
\end{aligned}
$$

Therefore, $t_{\text {score }}>t_{\text {table }}(0,05)$ with degree of freedom (df) $72,5,71>1,99(0,05)$ with df 72 .

Based on the calculation of the t-test where the value $t_{\text {score }}, 5,71$ is more than $t_{\text {table }}$ 1,99 at the level of significance 0,05 , it shows that the research hypothesis $\left(\mathrm{H}_{\mathrm{a}}\right)$ is accepted and the null hypothesis $\left(\mathrm{H}_{0}\right)$ is rejected. It means using learning model picture and picture increase students' ability to write procedure text in English.

\section{DISCUSSION}

Learning model pictures and pictures increases the students' writing procedures in ninth grade at SMP N 4 Takengon. The writer's experiment at SMP N 4 Takengon showed that the statement of the sentence above is true. Every element in this research correlates and is vital to answer the research problem, beginning from the title, theory, technique of data collection with the instrument of data, and analyzing the data to find the test result. Learning model pictures and picture is used a visual media. The writer tries as a learning model to teach English writing in the class, especially in procedure text, and the writer uses the test to collect the data.

The test shows that in the pre-test, the writer gets the result as follows: the control group average is 37,30 and experimental is 37,57 . In post-test, the control group is 61,08 , and the experimental group is 74,32 . The statement above shows that the result of the experimental group is higher than the control group.

From the test, the writer gets the result that the hypothesis $\left(\mathrm{H}_{\mathrm{a}}\right)$ is accepted. This statement, based on the result $t_{\text {score }}$ is more than $t_{\text {table. }}$. It concludes that the hypothesis is accepted so that the writer concludes that learning model picture and picture increase students' ability in writing procedure in ninth grade at SMP N 4 Takengon.

\section{CONCLUSION}

After this research is done at SMP N 4 Takengon, the writer can conclude that the learning model picture and picture can increase students' ability to write procedure text in English. This conclusion is based on the result of the average pre-test of the experimental group, which is 37,57 , and the post-test is 74,32 . The result of the average pre-test of the control group is 37,30 , and the post-test is 61,08 . From the explanation above, the writer compares the result of the experimental group as higher than the result of the control group. The learning model picture and picture can increase the students' ability to learn English, especially in writing.

During the writer conducting the research, there are some suggestions that the writer would like to argue that the students should be trying to write in English as habitual because it can help add more vocabulary and make the students have good writing. It is hoped that in studying English, the students should try to love the subject more because loving the subject is the biggest motivation in studying. It is hoped that the teacher to use learning model picture and picture in the class for teaching and learning English in the class. Besides that, make the students feel interested in learning English in the class. The school hoped that the school could provide the media because learning model picture and picture need media such as pictures and facilities to make the students active and creative 
and support them in learning English. The writer would like to suggest to other researchers to conduct further research with more time in experimenting to get and find the information of this theory. Based on the suggestion above we know that our educational improvement is uncompleted yet, because of that we must revise our education. It means the education is not only the responsibility of the teacher but also of society.

\section{REFERENCES}

Batubara, M. H., Herwanis, D., \& Safitriana, S. (2021). An Analysis Of Student's Error In Writing Ability Through Descriptive Text Of Vii Grade Of Smp $\quad \mathrm{N} \quad 4$ Takengon. Jurnal As-Salam, 5(2), 110-119. https://doi.org/10.37249/assalam.v5i2.276

Batubara, M. H., Rahila, C. D. I., \& Rahmadani, P. (2021). An Analysis On The Students' Error In Writing Report Text At Eight Grade Students Of Smp N 6 Timang Gajah. Jurnal As-Salam, 5(1), 10-19. https://doi.org/10.37249/assalam.v5i1.237

Boardman, A. (2002). Writing to communicate. New York: Longman.

Brown, H. Douglas. (2001). Teaching by Principles: An Interactive Approach to Language Pedagogy (second edition). New York: Longman.

Bukhari. (2010). Keterampilan Berbahasa Membaca dan Menulis. Banda Aceh: PeNa.

Depdiknas.(2004). Materi Pelatihan Terintegrasi Bahasa Inggris. Jakarta: Depdiknas.

Ellis, Arthur, et al. (1989). Elementary Language Arts Instruction. New Jersey: PrenticeHall.

Flower, L., \& Hayes, J. R. (1981). A cognitive process theory of writing. College Composition and Communication, 32(4), 365-387. https://doi.org/10.2307/356600

Flower, L.(1989). Problem Solving Strategies For Writing. United States of Amerika: Harcourt Brace Jovanovich Publisher.

Hamdani.(2011). Strategi Belajar Mengajar. Bandung: Pustaka Setia.

Harmer, J. (2004). How to teach writing. Essex, UK: Pearson Education.

Hayes, J., \& Flower, L. (1980). Identifying the organization of writing processes. In L. W. Gregg, \& E. R. Steinberg (Eds.), Cognitive processes in writing (pp. 330). Hillsdale, NJ: Lawrence Erlbaum Associates.

Hornby, A. S., Wehmeier, S., \& Ashby, M. F. (2003). Oxford advanced learner's dictionary of current English. Oxford: Oxford University Press.

Istarani. (2011). 58 Model Pembelajaran Inovatif. Medan: Media Persada.

Johnson, Andrew P. (2008). Teaching Reading and Writing: A Guidebook for Tutoringand Remediating Students. United States of America: Rowman \& Littlefield Publishers, Inc.

Mitchell, K. M., Harrigan, T., Stefansson, T., \& Setlack, H. (2017). Exploring selfefficacy and anxiety in first-year nursing students enrolled in a disciplinespecific scholarly writing course. Quality Advancement in Nursing Education, 3(1), Article 4. https://doi.org/10.17483/2368-6669.1084

Mitchell, K. M., Rieger, K. L., \& McMillan, D. E. (2017). A template analysisof writing self-efficacy measures. Journal of Nursing Measurement, 25(2), 205-223. https:// doi.org/10.1891/1061-3749.25.2.205

Neman, B.S. (1989). Writing Effectively, second edition. New York: R.R. Donnelley \& Sons Company.

Noth, W. (1995). Handbook of semiotics. Bloomington: Indiana University Press.

Nunan, D. (2003). Practical English language teaching. Singapore: McGraw Hill. 
Oshima, A., \& Hogue, A. (2007). Introduction to academic writing (4th ed.). New York: Pearson Education Press.

Richard. (2002). Methodology in Language Teaching: An Anthology of Current Practices. New York: Cambridge University Press.

Sampson, G. (1985). Writing systems: A linguistic introduction. Stanford, CA: Stanford University Press.

Setiawan, O. (2008). Genre. Bandung: Yrama Widya.

Suharsimi, A. (2006). Prosedur Penelitian Suatu Pendekatan Praktik, edisi revisi ke empat. Jakarta: Rineka Cipta.

Suyanto, K.K.E. (2008). English For Young Learners. Jakarta: PT. Bumi Aksara. 